\title{
The Effect of Autonomic Neural Control on the Cardiovascular System in Patients with Depression
}

\section{Depresyonlu Hastalarda Otonom Nöral Kontrolün Kardiyovasküler Sistem Üzerine Etkisi}

\author{
İbrahim Başhan ${ }^{* 1}$, Abdullah Tekin ${ }^{2}$, Hatice Göknur Tekin ${ }^{2}$
}

\begin{abstract}
Purpose: In this study, we aimed to examine hearth rate recovery, systolic blood pressure response to exercise and heart rate variability to reveal the effect of autonomic autonomic neural control on the cardiovascular system in depressed individuals. Methods: A total of 151 patients; (49 out of 75 healthy controls and 54 out of 76 patients with depression were females) were associated to age, sex and physical activity. We examined the difference between heart rate at peak exercise and heart rate recovery at related minute. Systolic blood pressure at $2^{\text {nd }}$ and $3^{\text {rd }}$ min of recovery was divided into the systolic blood pressure at peak exercise in order to determine blood pressure recovery indices. Results: Heart rate recovery at first minute was significantly lower in the depression group compared to the control group $(\mathrm{p}<0.0001)$. The resting systolic blood pressure was similar in both groups $(\mathrm{p}=0.762)$. Systolic blood pressure during peak exercise was significantly higher in the depression group compared to the control group $(\mathrm{p}<0.0001)$. In the depressive patient group, the systolic blood pressure recovery index was significantly higher at $2^{\text {nd }}$ and $3^{\text {rd }}$ minutes than the control group $(p<0.0001, p=0.015)$. Time domain and frequency domain parameters significantly decreased compared to the controls. Conclusion: This study demonstrates that depression is characterized with decreased heart rate recovery, exaggerated systolic blood pressure response to exercise and attenuated heart rate variability. These results may also propose alterations in autonomic neuronal control of the cardiovascular system in depression.
\end{abstract}

Key words: Depression, hearth rate recovery

\section{ÖZET}

Amaç: Bu çalışmada, depresyonlu bireylerde otonomik nöral kontrolün kardiyovasküler sistem üzerindeki etkisini ortaya çıkarmak için, kalp atım hızı düzelmesini, egzersize verilen sistolik kan basıncı cevabını ve kalp hızı değişkenliğini incelemeyi amaçladık. Yöntem: Toplam 151 hasta (75 sağlıkı kontrolün 49'u ve depresyonlu 76 hastanın 54'ü kadın) yaş, cinsiyet ve fiziksel aktivite ile ilişkilendirildi. Pik egzersizde kalp atış hızı ile ilgili dakikada gerçekleşen kalp hızı toparlanması arasındaki farkı inceledik. Toparlanmanın 2. ve 3. dakikasındaki sistolik kan basınc1, pik egzersizdeki sistolik kan basıncına bölünerek kan basıncı toparlanma endeksleri belirlendi. Bulgular: Depresyon grubunda birinci dakikadaki kalp hızı toparlanması kontrol grubuna göre anlamlı derecede düşük bulundu $(\mathrm{p}<0.0001)$. İstirahat sistolik kan basıncı her iki grupta da benzerdi $(\mathrm{p}=0.762)$. Pik egzersiz sirasında sistolik kan basıncı depresyon grubunda kontrol grubuna göre anlamlı derecede yüksekti $(\mathrm{p}<0.0001)$. Depresif hasta grubunda sistolik kan basıncının toparlanma indeksi kontrol grubuna göre 2 . ve 3. dakikalarda daha yüksekti $(\mathrm{p}<0.0001, \mathrm{p}=0.015)$. Zaman etki alanı ve frekans alanı parametreleri, kontrollere kıyasla önemli ölçüde azaldı. Sonuç: Bu çalışma, depresyonun azalmış kalp hızı toparlanması, egzersize abartılı sistolik kan basıncı cevabı ve azalmış kalp hızı değişkenliği ile karakterize olduğunu göstermektedir. Bu sonuçlar depresyonda kardiyovasküler sistemin otonomik nöral kontrolünde değiş̧iklikler olabileceğini ön görmektedir.

Anahtar kelimeler: Depresyon, kalp hızı toparlanması

Received / Geliş tarihi: 26.02.2018, Accepted / Kabul tarihi: 05.07.2018

${ }^{1}$ Mersin Üniversitesi Tıp Fakültesi Tıp Eğitimi Anabilim Dalı

${ }^{2}$ Başkent Üniversitesi Tıp Fakültesi Kardiyoloji Anabilim Dalı

*Address for Correspondence / Yazışma Adresi: İbrahim Başhan. Mersin Üniversitesi Tıp Fakültesi Tıp Eğitimi Anabilim Dalı, Mersin-TÜRKIYE, Email: ibashan@yahoo.com

Başhan İ, Tekin A, Tekin HG. The Effect of Autonomic Neural Control on the Cardiovascular System in Patients with Depression. TJFMPC, 2018;12(4):

258-263. DOI: $10.21763 /$ tjfmpc.462909 


\section{INTRODUCTION}

Cardiovascular diseases and depression are the most common causes of morbidity worldwide. It is usually observed in major depressive disorder with the development of cardiovascular disease. ${ }^{1}$ In addition, it has been shown that the mortality increases in coronary artery disease, after myocardial infarction ${ }^{2}$ and coronary artery bypass graft surgery. ${ }^{3}$ On the other hand, mechanism of this action is still unknown.

Although there are several hypotheses to explain the possible correlation between depression and cardiac disorders, most emphasized ones for patients with post-cardiac depression include their having more cardiac risk factors such as diabetes, hypertension and smoking, ${ }^{4}$ being less compatible in medical treatment, ${ }^{5}$ having increased inflammatory processes and autonomic nervous system disorders. ${ }^{6}$

It has been shown that the association between cardiovascular mortality and the autonomic nervous system is significant. ${ }^{7}$ The heart rate recovery (HRR) after exercise indicates parasympathetic activity $^{8}$ and the decay of parasympathetic activity is related to increased long-term mortality. ${ }^{9}$ Studies have shown that delayed recovery of systolic blood pressure (SBP) after peak exercise is a diagnostic finding and is related to excessive sympathetic activity. ${ }^{10}$ Also, the balance between sympathetic and parasympathetic nerve activities in heart has been shown through analyzing heart rate variations. $^{11}$ Hence, in this study we aimed to determine the autonomic neural activity by HRR, SBP after peak exercise and heart rate variability (HRV) in patients with depression.

\section{METHODS}

\section{Study Population}

This study was conducted in outpatient clinic of our University Hospital. A total of 151 patients were enrolled. Of these patients, 76 patients met the Diagnostic and Statistical Manual of Mental Disorders criteria for the diagnosis of depression. Seventy-five healthy subjects were enrolled as the control group. The Beck Depression Index-II was used to measure depressive symptoms. The diagnosis was made by the psychiatrist in charge. The groups were similar with regard to baseline age, body mass index and physical activity. The International Physical Activity Questionnaire (IPAQ) was used to match the physical activities of the groups. The patients with myocardial infarction or unstable angina or known coronary heart disease; hypertension or diabetes mellitus; heart failure or other known cardiomyopathies are excluded from the study. Patients with persistent laboratory abnormalities like kidney dysfunction, liver dysfunction or other significant non-cardiac diseases have not been included. Concomitant use of any antidepressant medications, reserpine, guanethidine, clonidine, methyldopa, anticonvulsants, neuroleptics, beta-blockers, calcium channel blockers ACE inhibitors or statins was another exclusion criteria. Psychiatric exclusion criteria included alcohol or substance abuse during the recent six months, psychotic symptoms, bipolar disorder, dementia, organic brain syndrome, risk of suicide, or psychotherapy support during the recent three months. Informed consent form was obtained from all participants and ethics committee approval was obtained from the Regional Ethics Committee prior to the study.

\section{Heart Rate and Blood Pressure Recovery}

The symptom-limited exercise tolerance test was performed in accordance with the modified Bruce protocol (using Quinton ${ }^{\circledR}$ treadmill system (Bothell, WA, USA)). SBP, heart rate and cardiac rhythm were examined during the each exercise phase and every minute after recovery for three minutes. After peak exercise, a 2-minute cool-down period at $1.5 \mathrm{mph}$ at a $2.5 \%$ grade was tested. The gap between peak exercise heart rate and heart rate at the related minute of recovery was calculated and HRR obtained. In one example, $1^{\text {st }}$ minute heart rate recovery (HRR1) was also calculated (at peak exercise HRR cool-down period $1 \mathrm{~min}$ ). Metabolic parameters were calculated in accordance with Standard Normograma. ${ }^{12}$

For measuring blood pressure, we used mercury column of sphygmomanometer. SBP recovery indices were determined as the ratios of the SBP recovery $1^{\text {st }}, 2^{\text {nd }}$ and $3^{\text {rd }}$ minutes of the peak exercise SBP.

\section{Heart Rate Variability Analysis}

The researcher was blinded to information about subjects obtained the HRV parameters from a 24-h electrocardiogram recordings and analyzed. The time domain indices were gathered as;

- SDNN: the standard deviation (SD) of R-R intervals.

- SDANN: the SD of the averages of R-R intervals at every 5-min in 24-h day

- pNN50: \% R-R intervals more than $50 \mathrm{~ms}$ vary from each other

- RMSSD: the root mean square of successive differences

- SDNN index: mean of the SD of all R-R intervals at every 5-min parts of the $24-\mathrm{h}$ recording

The frequency domain indices were obtained as;

- VLF: very low frequency (the power $\leq 0.04 \mathrm{~Hz}$ ) 
- LF: low frequency (the power between 0.04 to $0.15 \mathrm{~Hz}$ )

- HF: high frequency power (the power between 0.15 and $0.40 \mathrm{~Hz}$ )

- Total spectral power: the power between the 0.0 and $0.40 \mathrm{~Hz}$.

The measurements of power components were shown in definite values of power $\left(\mathrm{ms}^{2}\right)$.

\section{Physical Activity}

The physical activity of the subjects was standardized by using the International Physical Activity Questionnaire (IPAQ). The short version of IPAQ includes seven questions to determine the frequency and duration of subjects in potent, moderate-intensity, walking activity and the sitting time during a day. Scores are calculated in minutes per week and the sum of these scores has given an indicator of total physical activity.Additionally, as an energy expense indicator the metabolic cost (MET)- minutes per week was calculated. We multiplied the minutes per week for moderate and walking activity by average metabolic costs (MET) for these activities. (the IPAQ executive committee suggests 4 and 3.3 , respectively). ${ }^{13}$

\section{Statistical Analysis}

Table 1. Baseline characteristics of the study population

\begin{tabular}{|l|l|l|l|}
\hline Variable & \multicolumn{1}{|c|}{$\begin{array}{c}\text { Patients with } \\
\text { Depression (n=76) }\end{array}$} & \multicolumn{1}{c|}{$\begin{array}{c}\text { Controls } \\
(\mathrm{n}=75)\end{array}$} & p value \\
\hline Age $(\mathrm{yrs})$ & $37 \pm 5$ & $36 \pm 5$ & 0.877 \\
\hline Females (n) & 54 & 49 & 0.773 \\
\hline Body mass index (kg/m2) & $26.2 \pm 4.1$ & $25.3 \pm 4.4$ & 0.267 \\
\hline Total cholesterol (mg/dl) & $190.4 \pm 22.3$ & $180.7 \pm 34.1$ & 0.094 \\
\hline HDL cholesterol (mg/dl) & $46.4 \pm 13.0$ & $52.1 \pm 9.0$ & 0.125 \\
\hline LDL cholesterol (mg/dl) & $96.4 \pm 33.2$ & $85.9 \pm 32.1$ & 0.082 \\
\hline Triglyceride $(\mathrm{mg} / \mathrm{dl})$ & $155.6 \pm 27.2$ & $145.3 \pm 44$ & 0.097 \\
\hline Blood glucose (mg/dl) & $71.5 \pm 10$ & $67.6 \pm 9.7$ & 0.213 \\
\hline Physical Activity & & & \\
\hline Total physical activity (MET-min/week) & $1216 \pm 1029$ & $1342 \pm 1070$ & 0.620 \\
\hline Vigorous-intensity + activity (MET-min/week) & NA & NA & \\
\hline Moderate-intensity activity (MET-min/week) & $200 \pm 305$ & $915 \pm 418$ & 0.753 \\
\hline Walking (MET-min/week) & $962 \pm 450$ & $220 \pm 420$ & 0.650 \\
\hline
\end{tabular}

HDL, high density lipoprotein; LDL, low density lipoprotein; MET, metabolic equivalent. NA, not applicable

The data given in Table 2 contains the exercise test findings of the study groups. The exercise test was negative for the diagnosis of ischemia for all subjects. When the heart rate at peak exercise was compared with the resting heart rate, both groups were similar $(\mathrm{p}=0.855$ and 0.333$)$. The HRR1
We used SPSS (version 9.0) a commercially available statistical software package (Chicago, Illinois, US) for data analysis. For continuous data, the results are presented as mean value \pm standard deviations (SDs) and for categorical data as proportions. The Kolmogorov-Smirnov test was applied to verify whether the continuous variables showed a normal distribution. Unpaired t test was used for continuous variables with normal distribution and Mann-Whitney test was used for continuous variables with non-normal distribution. The power spectral measurements were converted to natural logarithms to actualize normal distribution in analysis when necessary. Chi-square or Fischer's exact test whichever appropriate were applied to analyze categorical parameters. Twosided level of significance was set at $\mathrm{p}$ values $<0.05$.

\section{RESULTS}

Table 1 shows the baseline clinical characteristics of the depressed patient group and the control group. Both groups had similar characteristics in terms of age, body mass index and physical activity. Furthermore, when compared with respect to biochemical parameters, the depressed patient group and control subjects had comparable parameters. values in the depressed patient group were significantly lower than the control group ( $p$ $<0.001)$. This result was largely based on high heart rate in the first minutes of recovery of depressed patients. The SBP values of both groups were similar at rest, but peak exercise SBP values in the 
depressed patient group were remained significantly increased ( $\mathrm{p}<0.001)$. In addition, the SBP values measured at the first, second and third minutes of recovery were higher in the depressed patient group when compared to controls. $(p<0.001$ first, second and third separately). Furthermore, the systolic blood pressure recovery index (SBPRI) assessed at $2^{\text {nd }}$ and $3^{\text {rd }}$ minutes was significantly higher in the depressed patient group than the control group ( $\mathrm{p}<0.01$ and 0.019 ). This finding indicates a delayed improvement in SBP at peak exercise in depressive patients.
Table 3 represents the HRV measurements of the study groups. The time domain and frequency domain parameters of the depressed patients were significantly lower than the control group.

\section{DISCUSSION}

As a result of this study, it was observed that depressed patients had decreased HRR1, extreme SBP responded with delayed recovery and attenuated HRV.

Table 2. Exercise test findings of the study population

\begin{tabular}{|l|l|l|l|}
\hline Variable & \multicolumn{1}{|c|}{$\begin{array}{c}\text { Patients with } \\
\text { Depression (n=76) }\end{array}$} & \multicolumn{1}{|c|}{$\begin{array}{c}\text { Controls } \\
(\mathrm{n}=75)\end{array}$} & p value \\
\hline Resting heart rate (BPM) & $85 \pm 13$ & $82 \pm 17$ & 0.333 \\
\hline Peak heart rate (BPM) & $180 \pm 9$ & $180 \pm 11$ & 0.855 \\
\hline Heart rate at 1.min of recovery (BPM) & $157 \pm 9$ & $148 \pm 12$ & 0.012 \\
\hline Heart rate at 2.min of recovery (BPM) & $139 \pm 10$ & $134 \pm 15$ & 0.295 \\
\hline Heart rate at 3.min of recovery (BPM) & $126 \pm 9$ & $120 \pm 10$ & 0.085 \\
\hline Heart rate recovery at 1 min (BPM) & $23 \pm 5$ & $32 \pm 6$ & $<0.0001$ \\
\hline Heart rate recovery at 2 min (BPM) & $40 \pm 9$ & $47 \pm 8$ & 0.059 \\
\hline Heart rate recovery at 3 min (BPM) & $53 \pm 6$ & $59 \pm 12$ & 0.044 \\
\hline Resting systolic blood pressure (mmHg) & $115 \pm 8$ & $114 \pm 10$ & 0.762 \\
\hline Peak systolic blood pressure (mmHg) & $175 \pm 15$ & $155 \pm 12$ & $<0.0001$ \\
\hline Systolic blood pressure at 1.min of recovery (mmHg) & $170 \pm 11$ & $146 \pm 11$ & $<0.0001$ \\
\hline Systolic blood pressure at 2.min of recovery (mmHg) & $164 \pm 13$ & $132 \pm 15$ & $<0.0001$ \\
\hline $\begin{array}{l}\text { Systolic blood pressure at 3. min of recovery } \\
\text { (mmHg) }\end{array}$ & $150 \pm 15$ & $125 \pm 10$ & $<0.0001$ \\
\hline Blood pressure recovery index at 1 minute & $0.96 \pm 0.05$ & $0.94 \pm 0.05$ & 0.882 \\
\hline Blood pressure recovery index at 2 minute & $0.92 \pm 0.03$ & $0.85 \pm 0.05$ & $<0.0001$ \\
\hline Blood pressure recovery index at 3 minute & $0.86 \pm 0.06$ & $0.80 \pm 0.10$ & 0.015 \\
\hline METs & $10.2 \pm 1.2$ & $11.8 \pm 1.7$ & 0.178 \\
\hline BPM, beat & & \\
\hline
\end{tabular}

BPM, beat per minute; METs, metabolic equivalents.

Table 3. Heart rate variability measures of the study population

\begin{tabular}{|l|l|l|l|}
\hline Variable & \multicolumn{1}{|c|}{$\begin{array}{c}\text { Patients with } \\
\text { Depression }(\mathrm{n}=76)\end{array}$} & \multicolumn{1}{|c|}{$\begin{array}{c}\text { Controls } \\
(\mathrm{n}=75)\end{array}$} & \multicolumn{1}{c|}{ p value } \\
\hline SDNN $(\mathrm{msec})$ & $120.5 \pm 24.3$ & $149.3 \pm 30.5$ & 0.003 \\
\hline SDANN $(\mathrm{msec})$ & $110.1 \pm 23.2$ & $135.6 \pm 30.3$ & 0.004 \\
\hline pNN50 $(\mathrm{msec})$ & $10.2 \pm 8.0$ & $18.0 \pm 9.6$ & $<0.001$ \\
\hline RMSSD $(\mathrm{msec})$ & $30.3 \pm 8.3$ & $39.5 \pm 12.3$ & 0.003 \\
\hline SDNN index $\left(\mathrm{msec}^{2}\right)$ & $50.3 \pm 12.4$ & $64.5 \pm 10.1$ & $<0.001$ \\
\hline HF power $\left(\mathrm{msec}^{2}\right)$ & $300.2 \pm 155.5$ & $470.3 \pm 225$. & 0.005 \\
\hline LF power $\left(\mathrm{msec}^{2}\right)$ & $670.1 \pm 232.1$ & $800.9 \pm 256.3$ & 0.022 \\
\hline VLF power $\left(\mathrm{msec}^{2}\right)$ & $1510 \pm 722$ & $2276 \pm 936$ & $<0.001$ \\
\hline LF/HF & $2.2 \pm 0.8$ & $1.7 \pm 0.6$ & 0.042 \\
\hline Total spectral power $\left(\mathrm{msec}^{2}\right)$ & $2336.7 \pm 1213.1$ & $3513.7 \pm 1084.3$ & $<0.001$ \\
\hline
\end{tabular}

SDNN, the standard deviation (SD) of all R-R intervals; SDANN, the SD of the avareages of R-R intervals during all 5-min periods that constitute the 24-h day; pNN50, percent of R-R intervals differing more than $50 \mathrm{~ms}$ from each other; RMSSD, the root mean square of 
successive differences; SDNN index, mean of the standard deviations of all R-R intervals for all 5-min segments of the 24-h recording; HF, high frequency; LF, low frequency; low

The increased heart rate during exercise develops partly due to decreased parasympathetic tonus. Heart rate recovery at the first minute during exercise is explained by the reactivation of vagal tone. ${ }^{8}$ Therefore, HRR1 after treadmill exercise was accepted as a marker of parasympathetic activity; decreased HRR has been associated with increased mortality. ${ }^{9}$ Markedly attenuated HRR1 in the depressed patients indicates reduced vagal activity in these patients.

The parameters affecting blood pressure; are left ventricular systolic function, heart rate and peripheral vascular resistance. Thus, the change in SBP during exercise is effected by the parasympathetic and sympathetic system and results in a cardiovascular response. ${ }^{14}$ The first response to the exercise is an increase in heart rate due to a decrease in parasympathetic tone. Subsequently, metabolic products and local mediators of exercise increase sympathetic stimulation and effect arterial tone. The observation of an extreme SBP response in depressive patients may result from the changes in this inexplicable mechanism. On the other hand, this finding may be a predictor of hypertension. ${ }^{15}$

Termination of exercise causes a decrease in heart rate and systolic blood pressure. This was different in our patients with depression. The heart rate at $2^{\text {nd }}$ and $3^{\text {rd }}$ minutes was similar between depression and control groups. However, blood pressure recovery indices were significantly higher in depressive patients at this time. This may be in consequence of the continuation of the increased sympathetic stimulation that increases peripheral resistance. Also, the finding that delayed postexercise blood pressure response is related to sympathetic hyperactivity was supported by others. ${ }^{10}$ Long-term activation of the sympathetic nervous system has been suggested as a possible mechanism revealing the relation of depression with cardiovascular diseases. ${ }^{16}$

Decreased HRV is an indicative of sudden cardiac events and death, with an important determinant of many cardiac events such as coronary artery disease, stable angina pectoris, heart failure after myocardial infarction, and death. ${ }^{17} \mathrm{HRV}$ is also used to describe the differences in autonomic functions. Decreased HRV finding is an indicative of a change in autonomic function in depressed patients. ${ }^{18}$ The reduced SDNN observed in this study was sugested to be an indicative of decreased parasympathetic and increased sympathetic activity in the sinus node. ${ }^{19}$ In addition, the RMSSD and pNN50 indices are defined as a sensitive and specific predictor of parasympathetic activity, with reduced RMSSD and pNN50 in depressed patients, a decrease in vagal activity compared to controls. ${ }^{20}$ In addition, a metaanalysis showed that high-frequency HRV was significantly lower in patients with major depressive disorder. ${ }^{21}$ Because high-frequency HRV is a marker of vagal activity, these findings support that depression is associated with reduced vagal inhibition.

This is the first study that examined HRR in unmedicated depression patients and healthy controls who were crosschecked according to physical activity. To date, a few studies have examined relations between depression and heart rate recovery with mixed populations. Hughes et al showed that the relationship between depression and HRR remained significant even after adjustments for resting HR, peak HR and total test time. ${ }^{22}$ Von Kanel et al suggested that HRR1 was not associated with depressed mood in chronic heart failure. ${ }^{23}$ It was found that BDI-II scores were not predictive of recovery even though there was a significant effect of major depression on 1-minute HRR. ${ }^{24}$ Our results indicate that the association between depression and delayed HRR cannot completely be attributed to lower fitness. The autonomic disorder in depression is probably characterized by sympathetic hyperactivity and vagal hypo activity; previously recommended by Thayer et al. ${ }^{25}$

The main limitation of this study is small sample size that limits the generalizability of the results. Also, methods used to determine autonomic nervous system activity until now cannot be considered as a 'gold standard' for assessment of adrenergic function. This study has some strengths like including patients who were not taking medications which could influence HRR and HRV.

In this study, we used a standard treadmill exercise test and heart rate variability analysis in patients with depression and healthy controls. These results may indicate the alterations in autonomic nervous system control of the cardiovascular system in depression patients.

\section{REFERENCES}

1. Nicholson A, Kuper $H$, Hemingway $H$. Depression as an aetiologic and prognostic factor in coronary heart disease: a metaanalysis of 6362 events among 146538 participants in 54 observational studies. Eur Heart J 2006;27:2763-2774.

2. Carney RM, Freedland KE, Miller GE, Jaffe AS. Depression as a risk factor for cardiac 
mortality and morbidity: a review of potential mechanisms. J Psychosom Res 2002;53:897 902.

3. Connerney I, Shapiro PA, McLaughlin JS, Bagiella E, Sloan RP. Relation between depression after coronary artery bypass surgery and 12-month outcome: a prospective study. Lancet 2001;358:1766 - 71 .

4. Carney RM, Freedland KE, Rich MW, Jaffe AS. Depression as a risk factor for cardiac events in established coronary heart disease: a review of possible mechanisms. Ann Behav Med 1995;17:142 -9.

5. Carney RM, Freedland KE, Eisen SA, Rich MW, Jaffe AS. Major depression and medication adherence in elderly patients with coronary artery disease. Health Psychol 1995; 14:88 - 90.

6. Writing Committee for the ENRICHD Investigators. Effects of treating depression and low perceived social support on clinical events after myocardial infarction: The Enhancing Recovery in Coronary Heart Disease Patients (ENRICHD) Randomized Trial. JAMA 2003;289:3106 -16.

7. Lown B, Verrier RL. Neural activity and ventricular fibrillation. N Engl J Med 1976;294:1165-1170.

8. Imai K, Sato H, Hori M, Kusuoka H, Ozaki H, Yokoyama $\mathrm{H}$ et al. Vagally mediated heart rate recovery after exercise is accelerated in athletes but blunted in patients with chronic heart failure. J Am Coll Cardiol 1994;24:152935

9. Cole CR, Foody JM, Blackstone EH, Lauer MS. Heart rate recovery after submaximal exercise testing as a predictor of mortality in a cardiovascularly healthy cohort. Ann Intern Med 2000;132:552-5

10. Kitaoka H, Takata J, Furuno T, Yamasaki F, Chikamori T, Doi YL. Delayed recovery of postexercise blood pressure in patients with chronic heart failure. Am J Cardiol 1997;79:1701-4

11. Heart rate variability. Standards of measurement, physiological interpretation, and clinical use. Task Force of the European Society of Cardiology and the North American Society of Pacing and Electrophysiology. Eur Heart J 1996;17:354-81

12. American College of Sports Medicine. ACSM's Guideliness for Exercise Testing and Prescription. Williams \& Wilkins 1995. p.153240

13. International Physical Activity Questionnairs (IPAQ): Short Last 7 Days Self-Administered Format For Use With Young And MiddleAged Adults. The final version of IPAQ from the 2000/01 Reliability and Validity Study. Completed May 2001. Available from: http://www.sdp.univ.fvg.it/sites/default/files/IP AQ_English_self-admin_short.pdf.

14. Ellis K, Pothier CE, Blackstone EH, Lauer MS. Is systolic blood pressure recovery after exercise a predictor of mortality? Am Heart J 2004;147:287-92.

15. Dlin RA, Hanne N, Silverberg DS, Bar-Or O. Follow-up of normotensive men with exaggerated blood pressure response to exercise. Am Heart J 1983;106:316-20.

16. Brosschot JF, Gerin W, Thayer JF. The perseverative cognition hypothesis: Areview of worry, prolonged stress-related physiological activation and health. J Psychosom Res. 2006;60(2):113-24.

17. Forslund L, Bjorkander I, Ericson M, Held C, Kahan T, Rehnqvist N et al. Prognostic implications of autonomic function assessed by analyses of catecholamines and heart rate variability in stable angina pectoris. Heart 2002;87:415-22.

18. Sandercock GR, Bromley PD, Brodie DA. The reliability of short-term measurements of heart rate variability. Int J Cardiol 2005;103:238-47.

19. Lombardi F. Clinical implications of present physiological understanding of HRV components. Card Electrophysiol Rev 2002;6:245-9.

20. Stein PK. Assessing heart rate variability from real-world Holter reports. Card Electrophysiol Rev 2002;6:239-44.

21. Kemp AH, Quintana DS, Gray MA, Felmingham KL, Brown K, Gatt JM. Impact of depression and antidepressant treatment on heart rate variability: A review and metaanalysis. Biol Psychiatry 2010;67: 1067-1074.

22. Hughes JW, York KM, Li Q, Freedland KE, Carney RM, Sheps DS. Depressive symptoms predict heart rate recovery after exercise treadmill testing in patientswith coronary artery disease: Results from the Psychophysiological Investigation of Myocardial Ischemia study. Psychosom Med 2008;70:456-460.

23. Von Kanel R, Saner H, Kohls S, Barth J, Znoj H, Saner G, Schmid J. Relation of heart rate recovery to psychological distress and quality of life in patients with chronic heart failure. Eur J Cardiovasc Prev Rehabil 2009;16:645650.

24. Gordon JL, Ditto B, Lavoie KL, Pelletier R, Campbell TS, Arsenault A, et al. The effect of major depression on post-exercise cardiovascular recovery. Psychophysiology 2011;48:1604-1609

25. Thayer JF. Vagal tone and the inflammatory reflex. Cleve Clin J Med 2009;76(2):23-26. 